\title{
The second attempt to negotiate the association agreement
}

\section{Introduction}

From the moment the EU and Mercosur stopped negotiations there was no progress or a real intention to restart the negotiations until 2010. Officially the EU and Mercosur continued negotiating the association agreement, but it is fair to say that after such a failure at the last minute in October 2004, both sides had become cautious in their hopes for a successful agreement. Considering that the negotiations had failed publicly, it is understandable that some years of 'healing' were needed before a new attempt could be broached.

One more time, the right momentum was necessary to facilitate the relaunch of the negotiations. The economic environment was completely different from 2004. At this moment Europe was recovering from a financial crisis and from a weak eurozone, while the international crisis had not had that much of an effect in Latin America. However, in 2004 Brazil and Argentina were recovering from the economic crisis of the late 1990s and early 2000s. The negotiations between the EU and other Latin American regional groups and individual countries had been successful. At the same time, a third major investor and trader became an important piece of the puzzle - China. To some extent this could be seen as a more promising context for reaching a successful agreement between the EU and Mercosur. The facilitator of the relaunching of the negotiations was once again the Spanish presidency of 2010. Since then, several meetings have taken place between the EU and Mercosur, the last one in Brussels in mid-June 2015. Throughout 2015, a new kind of scenario became possible - a two-speed type of negotiation: one with Brazil and other countries such as Uruguay and Paraguay, and another one with Argentina. Venezuela did not participate in the negotiations because its protectionist approach made it particularly difficult for the country to take part. Venezuela's restricted participation was further complicated by the fact that it became a member of Mercosur after the negotiations had already started. Considering both the views of 
Evo Morales and the economic development of this Andean country, Bolivia's potential membership of Mercosur would also further slow down the negotiations.

The overall argument is again supported through these negotiations. The EU's policy towards Mercosur is a reaction to the agenda being put forward by other actors. Mercosur in general and Brazil in particular are very keen to develop an agreement after the failure of the Doha Round. The facilitation of the negotiations had been made possible by the continued interest of the Iberian countries, especially Spain. The fact that Mercosur countries are willing to negotiate individually with the EU indicates how keen and proactive they are to develop this agreement. The diplomatic efforts of Spain were necessary in order to: (1) facilitate dialogue between the two regions; (2) bring Mercosur's views to the EU table; and (3) pursue a favourable EU reaction to Mercosur's suggestions.

\section{The relaunch of the negotiations and the actors involved}

The relaunching of the negotiations, as has been mentioned, was during the 2010 summit in Madrid. Although the negotiations had stopped in 2004, it did not mean a complete breakdown of the relationship. In fact, at the 2008 EU-Mercosur summit in Lima an agreement was signed to expand relations to three new areas: science and technology, infrastructure and renewable energy.

Leaders emphasized the close cultural, economic and political values which bonded the two regions together. They underlined that, with a combined population of more than 700 million people, high combined GDP and biregional trade close to $€ 100$ billion annually, cooperation between the two blocs generates reciprocal advantages and positive spillovers at the global level. 'The leaders are aware that substantial efforts will have to be made, and underlined their full commitment to engage in these negotiations' (EU-Mercosur). Both sides stressed their commitment to strive for a conclusion of the negotiations without delay' (EU-Mercosur Summit Joint Communiqué Madrid, 17 May 2010). In the meantime the EU continued to support the development of the Mercosur project.

The Regional Indicative Programme attached to the 2007-2013 EUMercosur Regional Strategy Paper outlined provisions for a total budget of $€ 50$ million, focusing on three key areas: institutional support, preparation for a future EU-Mercosur association agreement and support for civil society. After a mid-term revision, a decision was made to focus on two key issues: $€ 2$ million of support for the development of bio-technologies in Mercosur (replacing the previously anticipated support to strengthen Mercosur institutions) and $€ 15$ million towards further developing the Mercosur project, including the implementation of the future association agreement (European Commission 2015). 


\section{How did it happen?}

Just before the beginning of the Spanish presidency, there were talks about the relaunching of the negotiations between the EU and Mercosur. European foreign affairs ministers placed these negotiations within EU-Latin America relations, which also includes association agreements with the Andean Community and Central America (Agence Europe 10/12/2009).

It is important to understand that there were some substantial changes in context between the 1995 and 1999 agreements and the relaunch of negotiations in 2010 (Caetano et al. 2010). In the previous negotiations there was progress in the areas of cooperation and political dialogue, however there was little progress in terms of trade. Furthermore, there was a lack of progress in relation to dealing with the lack of social cohesion and the uneven distribution of economic and political power in Mercosur (Caetano 2010).

There are several reasons to believe that the EU considers the negotiations with Latin America relevant (Caetano et al. 2010). Caetano et al. point to reasons provided by Celestino del Arenal (2009), the most important of which are: a change in the international arena focusing more on the Asia-Pacific region; the international economic crisis and changes in US foreign policy; the enlargement of the EU and the shift towards right-wing governments across the EU; and the weakness of the Latin American lobbies.

It is of extreme importance to remember the asymmetries between the two blocs to understand the weight that each side carries in the negotiations. Table 7.1 shows the disparities that exist between the EU and Mercosur in terms economic resources. We also need to identify the EU and Mercosur's main trading partners before the relaunch of the negotiations in order to identify both the actors and the different interests which kick-started the relaunch of negotiations. Table 7.2 helps us to understand the priorities of different actors.

With the economic crisis having a profound impact and the lack of a successful outcome during the Doha Round of negotiations in 2010, Spanish and Argentinean presidencies of their respective was yet another for the relaunch of the negotiations. On the Mercosur side the possibility was discussed during the last summit in Montevideo in 2009. The official documents described the positive view:

Table 7.1 GDP of the EU and Mercosur, 2007

\begin{tabular}{lll}
\hline Region & GDP (millions) & GDP per capita \\
\hline Mercosur & $\$ 1,630,558$ & $\$ 6,753$ \\
EU-27 & $\begin{array}{l}€ 2,303,961 \text { (around } \$ 9,000,000-450 \% \\
\text { more than Mercosur }\end{array}$ & $€ 24,800$ \\
\hline
\end{tabular}

Source: Caetano et al. (2010). 
Table 7.2 Main trading partners of Mercosur countries and the EU-27, 2012

\begin{tabular}{|c|c|c|c|c|}
\hline $\begin{array}{l}\text { Main trade } \\
\text { partners of } \\
\text { Brazil }\end{array}$ & $\begin{array}{l}\text { Main trade } \\
\text { partners of } \\
\text { Argentina }\end{array}$ & $\begin{array}{l}\text { Main trade } \\
\text { partners of } \\
\text { Paraguay }\end{array}$ & $\begin{array}{l}\text { Main trade } \\
\text { partners of } \\
\text { Uruguay }\end{array}$ & $\begin{array}{l}\text { Main trade } \\
\text { partners of } \\
\text { EU-27 }\end{array}$ \\
\hline EU-27: $22.4 \%$ & Brazil: $26.8 \%$ & Brazil: $24.5 \%$ & Brazil: $17.8 \%$ & US: $15.2 \%$ \\
\hline US: $14.9 \%$ & EU-27: $18.7 \%$ & $\begin{array}{l}\text { Argentina: } \\
17.0 \%\end{array}$ & EU-27: $17.1 \%$ & China: $11.4 \%$ \\
\hline China: $9.7 \%$ & China: $11.5 \%$ & US: $15.2 \%$ & $\begin{array}{l}\text { Argentina: } \\
12.3 \%\end{array}$ & Russia: $9.7 \%$ \\
\hline $\begin{array}{l}\text { Argentina: } \\
6.2 \%\end{array}$ & US: $10.9 \%$ & EU-27: $9.4 \%$ & China: $10.8 \%$ & $\begin{array}{l}\text { Switzerland: } \\
6.2 \%\end{array}$ \\
\hline Japan: $4.7 \%$ & Chile: $4.3 \%$ & China: $7.3 \%$ & US: $7.5 \%$ & Norway: $4.7 \%$ \\
\hline Nigeria: $4.1 \%$ & Mexico: $2.5 \%$ & Mexico: $2.5 \%$ & $\begin{array}{l}\text { Paraguay: } \\
4.6 \%\end{array}$ & \\
\hline Chile: $3.5 \%$ & $\begin{array}{l}\text { Paraguay: } \\
1.6 \%\end{array}$ & $\begin{array}{l}\text { Paraguay: } \\
1.6 \%\end{array}$ & Mexico: $3.0 \%$ & \\
\hline $\begin{array}{l}\text { South Korea: } \\
2.3 \%\end{array}$ & Russia: $1.6 \%$ & $\begin{array}{l}\text { Uruguay: } \\
1.5 \%\end{array}$ & Nigeria: $3.0 \%$ & \\
\hline Mexico: $2.2 \%$ & Uruguay: $1.5 \%$ & Japan: $1.3 \%$ & Russia: $2.5 \%$ & Brazil: $2.2 \%$ \\
\hline Russia: $2.1 \%$ & Japan: $1.3 \%$ & & $\begin{array}{l}\text { South Africa: } \\
2.3 \%\end{array}$ & \\
\hline
\end{tabular}

Note: Figures are percentage of total foreign trade.

Source: http://europa.eu/.

[the Presidents] celebrated the Meeting between Mercosur and the European Commission in Lisbon on November 4 to 6, 2009, and expressed their support to furthering the relations, inclusively before the end of 2009, between the future Pro Tempore President of Mercosur (Argentina) and the European Commission as well as advancing work in order to reach the greatest possible progress in the negotiations in view of the presidential meeting scheduled within the LAC-EU Summit for May 2010 under Spain's EU Presidency. (Pena 2009)

At the same time, the pressure on Mercosur also came from other actors that had been present during the previous negotiations - the business associations. The presidents of the MEBF, Inaki Urdangarin on the European side and Carlos Mariani Bittencourt on the Mercosur side, provided a declaration to the four Mercosur countries explaining the need to end the 
negotiations successfully (Pena 2009). It is interesting to see that even at the time of the relaunch of the negotiations there was an attempt to create a two-speed process that would facilitate flexible negotiations (Pena 2009). In doing so, it seems that different degrees of commitment were expected by certain Mercosur countries. This issue will be explored further at the end of this chapter.

The EU decided to relaunch the negotiations with Mercosur as there were clear economic benefits for both the EU and Mercosur (European Commission 2010). According to the European Commissioner for Trade, Karel De Gucht:

negotiations such as these are challenging but the moment is right to take a fresh look at the state of discussions so far. Any agreement must be ambitious bringing increased access for a range of EU businesses, including agriculture, into the Mercosur region. It is critical that certain key EU demands are met if these negotiations are to be fruitful at the end of the day. (European Commission 2010)

The biggest obstacle to the agreement was the negotiations in the agriculture sector. The EU wanted better access to the industrial sector, while Mercosur asked for lowers obstacles to their agricultural exports to Europe.

Once again Spain and Portugal were key actors in terms of facilitating EU-Mercosur relations. After the actions of the Iberian countries have been discussed, the remainder of this chapter will focus on the actions of other EU countries. The relative importance of these negotiations in EU external issues does not generally provoke discussion and opinions in the twentyeight countries, and therefore the analyses will focus on the countries that have a strong opinion on this policy - France, Ireland and Greece - since they are the ones acting in a distinct way. After focusing on the EU member states, the discussion will turn to focus on the role of EU institutions, particularly the actions of the European Commission and the EP, which have had opposing views on this policy. Finally we will examine how the position of Mercosur countries has been underestimated by showing that they did have considerable influence in the relaunch, as they had done the first time around in the 1990s.

\section{The European Union}

\section{Spain and Portugal}

The Iberian countries traditionally give more importance to EU relations with Latin America than other European countries do. The Iberian support for the relaunch of the EU-Mercosur negotiations has been shown on several occasions. In November 2009 - almost a month before the start of the Spanish presidency, there was a meeting in Madrid where the role of Spain was specifically discussed by Juan Pablo de Laiglesia, the Spanish secretary of state for Iberoamerica (El País 25/11/2009). Here it was decided 
that they would push for the negotiations at the following Iberoamerica summit a month later (El País 25/11/2009).

The importance of the Spanish presidency of the EU in advancing the negotiations with Mercosur was highlighted by the director of the European Commission on Latin America (El País 25/11/2009). On the other side of the Atlantic, this was also observed when an MEP claimed: 'if with the Spanish presidency there is not progress with Latin America, forget about it' (Clarin 2/1/2010). The sub-secretariat of economic integration in Mercosur, Eduardo Sigal, admitted that the Spanish presidency and the role of Spain was one of the key factors in terms of improving this relationship (Clarin 7/3/2010). Moreover, the Spanish vice-president at that time went to Buenos Aires to discuss the issue with the president of Argentina and was straightforward: 'This is a very important occasion, it is not going to be repeated in a long time, Spain will preside over the EU, and Argentina over Mercosur, and we both can influence the priorities and the agendas of the organizations' (El País 9/11/2010) Spain knew that the next presidencies of the EU would ignore Latin America and therefore pressed forward any agreement talks with this region (Agence Europe 20/5/2010).

Spain planned and tried to conclude negotiations with Mercosur during the six months of its presidency, but it was obvious that there were some doubts about what could be achieved. According to the Spanish minister of foreign affairs, Moratinos: 'We will continue the ambitious negotiations but will it be possible to conclude talks by May? It is difficult to say but we will do all we can to achieve this in Madrid' (Agence Europe 5/2/2010). Statements such as this reveal just how different the political rhetoric was from the reality of the negotiations. The conclusion of the negotiations in May 2010 was entirely unfeasible.

\section{Other EU countries}

Although there was complaints from France during the first EU-Mercosur association negotiations, the number of countries complaining increased considerably during the second round of negotiations. Crucially, during the negotiations that ended in 2004, there was only fifteen EU member states. By the time of the second round of negotiations the EU had expanded to twenty-eight member states. Moreover, most of the new members considered the agricultural sector to be important to their national economies. In 2010 the economic situation was not the same as it had been in 2004, especially for countries such as Ireland and Greece.

These complaints increased in intensity in the weeks before the summit of the heads of state of the EU and Latin America which was held in May 2010 in Madrid, during the Spanish presidency of the EU. The French minister Bruno Le Maire declared that the EU could not go ahead with the negotiations due to the negative influence that they would have on the 
French and European agricultural sector (Clarin 6/5/2010; El País 7/5/2010). In fact, the main farmers' trade union in France asked French President Nicolas Sarkozy to veto the negotiations altogether (El País 7/5/2010). Bruno le Maire argued that the EU had already made concessions that would benefit the Brazilian agricultural sector during the Doha Round negotiations in July 2008 (Clarin 6/5/2010). On the other side, the Argentinean newspaper, Clarin, criticized that fact that France received more than $20 \%$ of the aid budget that provided for the agricultural sector, which disadvantaged Mercosur agricultural products (Clarin 6/5/2010). This debate echoes the situation in the late 1990s before the first Rio Summit, as has been explained in Chapter 4.

Initially, seven countries expressed their dissatisfaction when the European Commission announced on 4 May 2010 that the negotiations would be resumed: Austria, Finland, France, Greece, Hungary, Ireland and Poland (Agence Europe 15/5/2010). A few days later, the ministers of agriculture of several EU countries complained again about the official relaunch of the negotiations on 17 May 2010 during the summit: Austria, Belgium, Cyprus, France, Greece, Hungary, Ireland, Italy, Lithuania, Luxembourg, Poland, Portugal, Romania, Slovenia and Slovakia (Agence Europe 18/5/2010). The argument used was again related to the concessions granted in July 2008 and the fact that the countries felt that they would pay for the concessions twice, leading them to ask the Commission to conduct further research into the effects of this agreement.

The level of dissatisfaction continued, this centring on the discussions relating to, among other things, the standard of Brazilian products, with the French minister Bruno Le Maire arguing that: 'agriculture is not an exchange currency. We will not go further on the negotiations with the WTO. Europe is not an outlet for agricultural products from South American countries' (Agence Europe 16/9/2010). The Irish MEP Marian Harkin also complained that 'the Russians and the Americans will not permit the importation of Brazilian beef and have good reasons for those decisions. The EU has been far less demanding in regard to standards and traceability of food products. Commissioner De Gucht's suggestion that a trade agreement would benefit EU exporters and investors has to be viewed with suspicion' (Agence Europe 16/9/2010). The answer from European Trade Commissioner De Gucht was clear: 'The Commission does the negotiating, and it has to be respected. The French position is well-known - it's the same as it always says' (Agence Europe 18/9/2010). A few months later the Irish Farmers' Association claimed that De Gucht had failed to represent European interest, while also accusing the trade commissioner of double standards when dealing with EU and non-EU agricultural products (Agence Europe 23/2/2011). It is clear by now that both France and Ireland were the countries that most vehemently rejected the negotiations. However, Mercosur had a supporter of some weight within the EU. The German 
Chancellor, Angela Merkel supported the agreement and considered it beneficial for Europe (Clarin 18/10/2011).

\section{European Union}

The EU decided to relaunch the negotiations in 2010 but it is crucial to remember that, only a couple of years before, there had been no intention on either side to relaunch them until the Doha Round was completed (Agence Europe 20/5/2008). This supports the overall argument of presented throughout this monograph: that there was a lack of a clear EU strategy towards Mercosur. In fact, the EU followed the momentum created every so often by the Spanish and Portuguese presidencies of the EU to improve EU-Mercosur relations. More often than not, any momentum in this direction was not initiated by the EU, even though Commissioner Ferrero-Walder tried to give a different impression during the EU-Latin American Summit of 2008: 'We are confident that, if we continue with the same will, we will be able to conclude the agreements before the end of 2009' (Agence Europe 7/5/2008). At the same time, Ferrero-Walder hoped that the summit would give 'renewed momentum' to the WTO. This, again, suggests that there was clear discrepancy between the rhetoric and reality when it comes to the progress of these negotiations.

In 2010, the Spanish presidency of the EU and the Argentinean presidency of Mercosur lead the European Commission to believe that there was now right the momentum required time to relaunch negotiations (El Pais 25/11/2009). As the Spanish Minister of External Affairs pointed out, the Doha negotiations was going nowhere at this point (El Pais 25/11/2009). It was in this moment that the Director of the Latin American Area for the European Commission admitted that in the context of the financial crisis both regions needed new markets to help improve their respective economic situations (El País 25/11/2009). However, it seemed that in contrast to France and Germany, some countries within the EU, such as Spain, were willing to be more generous towards Mercosur (El País 25/11/2009).

During the negotiations, the EU clearly accused Mercosur in general and Argentina in particular of being responsible for stopping the progress between the regions. In fact, Commissioner De Gucht directly accused Argentina's protectionist stance of causing problems to the point where he threatened the Mercosur country with an official complaint to the WTO (Clarin 15/4/2011). Here De Gucht was alluding to the barriers faced by European exporters to Argentina - a matter that had also been raised by several EU countries. Argentina responded immediately, claiming that the De Gucht was trying to create divisions amongst Mercosur countries (Clarin 15/4/2011). However, in contrast to Argentina, it seems that Paraguay and Brazil were showing greater more flexibility in their efforts to reach an 
agreement, although Argentina would claim that Brazil was simply just better at disguising its real strategy (Clarin 5/5/2011). Support for the agreement also came from other EU actors such as Catherine Aston; the EU high representative for foreign affairs stated that 'negotiations with Mercosur must be resumed' (Agence Europe 22/4/2010).

\section{Mercosur}

The discussion of the negotiations should cover the views of all the actors, especially since Mercosur has been very active in EU-Latin American relations. Mercosur countries wanted this agreement in the first place, and it was felt that the second opportunity which the Spanish presidency of 2010 presented was not to be ignored. Argentina and Brazil tried to put aside their problems and drive the agreement (El Pais 18/5/2010). At this point, there were several reasons why Mercosur wanted to reach an agreement. While Uruguay had always supported the agreement, the reasons for reaching an agreement included improving Argentina's image on the international stage through an agreement with the EU, and broader concerns within Mercosur that Brazil would make its individual agreements with the EU ( $E l$ País 18/5/2010).

Argentina had always been the Mercosur country with deeper reservations regarding any agreement with the EU (El País 18/4/2010), and on this occasion, Argentina again presented further some obstacles in terms of blocking imports from the EU. Countries affected by this issue, such as Greece, complained directly at the European level since it violated international norms of commerce, and the EU as a consequence asked Argentina to halt these actions (Clarin 28/6/2010). It also seems that Greek exports, valued at $\$ 2,400$ million, had also been cancelled or suspended (Clarin 28/6/2010). When Greece asked Argentina for an explanation, the latter refused to give one. As a result Greece threatened to block negotiations between the EU and Mercosur (Clarin 28/6/2010). Argentina justified the blocking of exports as being occasional rather policy and they claimed in a meeting of the WTO that the European accusations were politically motivated (Clarin 5/7/2010).

Brazil tried to keep the negotiations going. This included President Lula organizing meeting in Brasilia with the president of the European Commission, José Manuel Barroso, and the president of the European Council, Herman Van Rompuy (El País 15/7/2010a). Brazil had been in a similar position with Argentina, with Brazilian products being blocked at the Argentinean border. However, on this occasion Lula was trying to progress the required preparatory work for reaching an agreement before he left the Brazilian presidency (El País 15/7/2010a). When discussing his role as president of Mercosur, Lula clearly stated that: 'I have assumed the presidency of Mercosur and I have the task of trying to persuade the EU to sign 
an agreement' (Agence Europe 17/7/2010). Lula also referred to the French president's view on the agreement, noting that: 'As the comrade who has done most ... is my great friend Nicolas Sarkozy, it will be my responsibility to try to convince [him], to win the hearts of the French to get this agreement before the end of my presidential term of office' (Agence Europe 17/7/2010).

At the same time, Argentina needed both the EU and Spain to be more diplomatic if it was to be persuaded to change its stance towards Europe. This led to the Argentinean president holding discussions with the president of the European Commission, José Manual Barroso in 2008 during the EU-Latin America summit, as well as further talks with the Spanish vicepresident during her visit to Buenos Aires in 2009 with a view to improving political relations (El País 18/4/2010).

Another reason for Argentina to improve relations with the EU and Spain was to improve the image of Mercosur (El País 18/4/2010). The accusations of lack of progress in the Mercosur integration project came from all sides, including Latin American countries. At this stage, Uruguay considered that the end of 2010 pivotal for the integration project in Mercosur, primarily because of the lack of political economic coordination in Mercosur and the growing strength of other regional projects such as the Union of South American Nations (UNASUR) (El País 10/12/2010). Even Spanish politicians such as Carlos Solchaga, the former Minister of Finance, commented on the fragility of the Mercosur project (El Pais 15/7/2010b). However, the most worrying issue for Argentina was the fact that some sectors in Brazil wanted to develop individual agreements with the EU, believing that Brazil could further advance its own interest independently of the other Mercosur countries (El País 17/7/2010).

\section{Mercosur: a happy family of five?}

As well as the lack of regional integration, Mercosur had to deal with two difficult issues that were, to some extent, interlinked: the suspension of Paraguay's membership of Mercosur and Venezuela becoming a Mercosur member state. To be more specific, a political crisis in Paraguay provoked the suspension of its membership of Mercosur, which was used as an opportunity to let Venezuela officially join the regional group.

In June 2012 the president of Paraguay was removed from office, allegedly in response to the way that he had handled domestic issues such as the massacre at Curuguaty, and his choice of the security minister without consulting the government's coalition partners (MercoPress 18/4/2013). President Lugo had three days to respond, after which the Senate voted against him, the Senate with 120 out of 125, to remove him from office. Lugo was later replaced by Federico Franco, who at the time was the country's vice-president (MercoPress 18/4/2013). Mercosur and UNASUR 
claimed that this was a coup and suspended Paraguay's membership of Mercosur was suspended until after the next general election in Paraguay. In fact, Paraguay was also suspended from other groups and summits which included the Iberoamerican summit, the meeting of Latin American and Arab countries and the Community of Latin American and Caribbean States (CELAC) (MercoPress 26/1/2013). However, with the support of the US and Canada, Paraguay managed to remain a part of the Organization of American States, even though Argentina, Uruguay, Brazil, Venezuela, Bolivia, Peru, Ecuador, Cuba and Nicaragua did not agree (MercoPress 26/1/2013). According to the head of the Paraguayan delegation to the Parliament of Mercosur, the suspension from so many forums was orchestrated, with Argentina, Brazil and Venezuela masterminding the plot to limit Paraguay's influence in the international arena.

In January 2013 Paraguay decided not to attend the EU-CELAC summit after Mercosur and UNASUR countries had argued that Paraguay should not be invited (MercoPress 26/1/2013). In fact, the Paraguayan president, Federico Franco stated that 'Paraguay had not been invited' (MercoPress 26/1/2013). This was a critical moment in diplomatic relations given that Paraguay had not encountered any problems with CELAC.

By April 2013 Paraguay was still dealing with this diplomatic problem. However, attention had shifted to the upcoming Paraguayan national elections. In order to ensure that the elections were democratic, the elections were observed by, among others, three Nobel Prize-winners, the EU and the Organization of American States (MercoPress 18/4/2013). Occupying an increasingly peripheral position in the international arena meant that Paraguay could not object to such an imposition.

The suspension of Paraguay was used by the other Mercosur countries as a chance to incorporate Venezuela in the regional group; because of its long-standing political dislike of Venezuelan president Hugo Chavez, Paraguay had for years refused to allow Venezuela to become a member of Mercosur. This created even more friction between Paraguay and Venezuela, particularly between Chavez and Paraguay. Even after Nicolas Maduro became president after Chavez's death, relations did not improve, primarily because Maduro appeared to support the President Lugo following the aforementioned calls from the Paraguayan Congress that he be removed from office. In fact, Maduro called for the Paraguayan people to take to the streets to protest against Lugo's removal (MercoPress 18/4/2013). For Paraguay, however, what really mattered was that the EU acknowledged that Paraguayan was part of Mercosur and that Paraguay could rejoin Mercosur's negotiations with the EU (MercoPress 18/4/2013). Brazil played a key role as a regional leader in forcing Paraguay to accept Venezuela as a member of Mercosur. In principle the suspension was until the elections were held, but after the elections Brazil set the condition that Paraguay could only return to Mercosur if it gave its approval to the Venezuelan 
membership (MercoPress (23/4/2013). What this issue again reveals is that there were clear asymmetries of power within Mercosur.

At this point, Paraguay demanded respect for 'the country's dignity and rule of the law' (MercoPress 27/5/2013). It was felt that Venezuela's membership of Mercosur had been imposed on Paraguay because the latter's Congress had not ratified the former's membership. By June 2013 Paraguay stated its intention to become a member of the Alliance of the Pacific (MercoPress 16/6/2013). This should be seen as a move towards Mercosur's 'rival' regional group in Latin America, which not only expressed a more liberal agenda, but also enjoyed better relations with the US. Paraguay also had other options apart from Mercosur. The balance of power had certainly changed in Latin America since the creation of Mercosur, and this would have an impact on the need to develop agreements with other regions and countries, particularly in relation to the EU. If the non-Mercosur countries achieved individual better agreements with the EU and the US, this would negatively affect Brazil, Argentina, Paraguay and Uruguay because their exports were not that different from other Latin American countries in terms competitive agricultural and farming products. This helps us to see the economic reality for countries and regional groups such as the Alliance of the Pacific and Mercosur. However, there was also the political agenda at play. Mercosur had not embraced neoliberal economic policies in the same way that the Alliance of the Pacific had done. Changes in the regional power dynamics were also evident: Mercosur, with the weight of Brazil and Argentina, could be seen as the main regional leader, until Mexico and Chile came together with other Latin American countries to form create the Alliance of the Pacific.

Matters were not helped in the first half of 2014 when it was the turn of Paraguay to hold the presidency of Mercosur, which instead was passed to Venezuela. From a diplomatic point of view, Mercosur in general and Brazil in particular behaved in a high-handed way. Paraguay tried to use the weight of the EU to support its case. According to a representative of Paraguay: 'There's no need to rush, Mercosur has a low rating in international politics. Mercosur has violated the law. The European Union will not negotiate with an entity that violates the law and, as comments from acknowledged personalities from Argentina and Brazil have stated, Mercosur is disintegrating politically and juridically' (MercoPress 16/6/2013).

At the same time, Venezuela tried to become an accepted by the other countries as member of Mercosur. For example, it supported the negotiations with the EU but did not demand that it participated in them. Also, Maduro promised to the left-wing president of Uruguay, José Mujica, a 'permanent' supply of petroleum, as well as the signing of a strategic alliance in the energy sector (MercoPress 8/5/2013).

Brazil attempted to mediate in Venezuelan domestic politics, asking Maduro to develop a political dialogue with his political opponents, 
including Henrique Capriles (MercoPress 14/5/2013). At the same time, Brazil was prepared to supply emergency shipments of food, up to 700,000 tonnes, to help the Maduro administration (MercoPress 14/5/2013).

Other problems that had to be dealt with in Mercosur involved the lack of economic and political consensus between Brazil and Argentina, a situation in which other Mercosur countries were reluctant to intervene. The level of economic and political disagreement between these two countries was not the same level as that which existed between Venezuela and Paraguay. The presidents of the two countries, Fernandez and Rousseff, had different views on both investment and trade - an issue which had the potential to affect the very foundations of Mercosur (MercoPress 20/5/2013). In addition to this, Argentina had started to develop strong links with Russia as a response to the nation's severe economic problems and more specifically because of its high levels external debt. Since Argentina's economic problems would, sooner or later, have an impact on the Brazilian economy, it was widely felt that Brazil should be the one helping Argentina as one of its main trading partners (El País 1/8/2014).

\section{The 2015 Brussels Summit: the end of biregional negotiations?}

The summits that took place in 1999 between the EU, Latin American and Caribbean countries are indicative of the way that cooperation developed between these regions. However, over time, these summits became an increasingly difficult forum within which to develop bilateral discussions due to expanding number of participants taking part in the discussions (Maihold 2009).

The impetus for the first EU-Latin America summit (Rio de Janeiro, 1999) came from Iberia. It was Spain who would put forward the idea during the Iberoamerican summit of November 1996. This was considered to be the exact moment to try and further advance biregional relations into the twenty first century. The role of Spain in pushing for this particular, and also subsequent, summits was key (Maihold 2009). The second summit (Madrid, 2002) was key feature of the Spanish presidency of the EU and was used to boost the cooperation and negotiations between the EU with regional groups such as Mercosur. The 2010 summit in Madrid further demonstrated Spanish interest in relaunching EU-Mercosur negotiations and the signing of the EU-CACM agreement. Although these summits put pressure on both sides to reach agreements, the declarations emerged from the meetings were, despite good intentions, considered to be rather vague. However, these summits did help to create an EU-Latin American agenda that was subsequently used to reach common positions in relation to issues discussed at other international forums such as the United Nations (Maihold 2009). Furthermore, these summits were also occasionally used by various national presidents to enhance their own personal image and to project their 
personalities as playing a key role in the outcome of the summit (Maihold 2009). The politicization of the summits - as was the case of the 2010 and 2013 summits - can also negatively affect the development of agreements, especially if a country's president feels the need to react to the fact that other countries have tried to sabotage their attendance at a summit in response to internal national political issues, as happened with Honduras in 2010 and Paraguay in 2013.

In 2014 there were also several announcements that there would be a renegotiation of tariffs, but this did not happen. According to the president of Brazil, Dilma Rousseff, the South Americans created barriers to the proposals while the EU was more proactive. The negotiations have taken so long and the reasons for this were deemed to be quite evident and so difficult to overcome that the option of negotiating individual national agreements with the $\mathrm{EU}$, as opposed to a broader regional group agreement, was considered to be a more feasible solution for some of the Mercosur countries. The former president of Uruguay, José Alberto 'Pepe' Mujica, claimed that the Mercosur project had stalled and risked becoming obsolete if it did not have needed trade agreements with third parties. According to Mujica, Mercosur had become a 'poor customs union' (MercoPress 2/3/2013): 'We can't and should not cheat ourselves: in recent years Mercosur is stalled and with growing difficulties to trade among its partners ... although there is the manifest bilateral determination which we believe will continue to advance with Brazil ... The truth is that in the whole bloc we have pachyderm size difficulties to advance or to try to advance' (MercoPress 2/3/2013). Mujica also issued a warning about the state of negotiations between the EU and the US: 'How do you penetrate such a huge free trade space? We must lift our heads and look around to what is happening in the world. Imagine the growing difficulties for those left out in the cold to have access to those agreements' (MercoPress 2/3/2013).

According to a representative of Brazil, it was EU Commissioner De Gucht who suggested that they cancel the following meeting where both blocs were meant to exchange proposals for the agreement. The EU insisted that they had not given up and that they were waiting to hear positive news from Mercosur in order to speed up the negotiations (Clarin 13/12/2013).

For the EU, the main problem was Argentina since the other three countries had offered the expected outcome which stated that $90 \%$ of products would not be subjected to custom tariffs, while Argentinean president, Cristina Fernandez would offer no more than $80 \%$ (Clarin 13/12/2013). Mercosur adopted a two-speed approach so that Argentina could move more slowly, even though it was felt that the EU would rather see Argentina on the outside of the agreement (Clarin 13/12/2013). Just before the summit in Brussels in June 2015, the president of Brazil warned Argentina of the risk of being left behind (Clarin 11/6/15). In Brussels, Brazil announced that Mercosur was ready to present an offer, while at the 
same time appearing to put pressure on Argentina, who were opposed the agreement (Clarin 11/6/15). This was similar to what had happened in 2004, when again it was Argentina that had refused to sign the agreement at the last minute. In 2015, Argentinean representatives also disagreed with the timetable that Brazil had offered to Europe (Clarin 11/6/15). It is also crucial to point out that the president of Argentina, Cristina Fernandez had decided not to attend the summit.

Given that Brazil needed to improve the competitiveness of its exports, they therefore felt that negotiations had to begin as soon as possible. However, the renegotiation of tariffs had to be done by both sides at the same time, meaning that the EU would also have to agree to the renegotiate tariffs (Clarin 11/6/15). In contrast to Brazil, the respective interests of the other Mercosur countries were equal, if not even higher. For example, Uruguay had signed a cooperation agreement with the EU and other developing countries. Uruguay explained how important this agreement with the EU was and that it would reach agreement one way or another (Clarin 11/6/15).

The fact that Mercosur needed to negotiate as a group is something that was brought to the discussion because it seems that many South American countries wanted to change this rule so that they could develop their own intendent national-level agreements with the EU. In fact, two weeks before the summit in Brussels, both Uruguay and Brazil discussed the excluding Argentina from the discussions with the EU (Clarin 4/6/2015). Both countries also appeared to be worried about being displaced by the US when it comes to food exports (Clarin 4/6/2015).

Uruguay also admitted that it had tried to advance talks with the EU on its own during the Brussels Summit, while Brazil waited for the outcome of the elections in Argentina to initiate a change in negotiation with the EU (Clarin 9/6/2015). In a manner similar to Uruguay, Paraguay had also discussed the negotiation of an individual trade agreement with the EU ( $\mathrm{La}$ Nacion 11/5/2015).

Brazilian agricultural groups also pointed out that it was extremely important to sign the Mercosur regional agreement with the EU and that if Argentina did not want to participate, Mercosur should push on with the negotiations (El País 25/2/2014). At the same time, they were also concerned about negotiations between the EU and the US which could have had a catastrophic impact on the Brazilian agricultural sector (El País 25/2/2014).

According to European Commissioner Cecilia Malmstrom, there was a need for more technical meetings before renegotiation of tariffs could take place (MercoPress 12/6/2015). Malmstrom also explained that attempts were being made to progress further discussions, claiming that the negotiations are 'in a dead-end street ... we are seeing if we can find an exit ... there is willingness' (Iprofesional 20/4/2015). Malmstrom also suggested that there are problems with the level of ambition being expressed: 'it needs 
to be seen if the ambitions are the same, if we want the same, there are discussions [sic] meetings to see if it is the case' (Iprofesional 20/4/2015). Spain also seemed to be suggest that a pragmatic agreement between the $\mathrm{EU}$ and Mercosur which would also sanction individual agreements between Mercosur countries and the EU (EUBrasil 27/4/2015), while it also appears that the EU was considering the same issue.

Christian Leffler, head of the EU Desk for the Americas, did not discount the possibility of advancing separate national-level agreements with Mercosur as long as this became 'an official, formal communication'. In fact, Leffler admitted during a video conference with Latin American journalists: 'At that point we would have to consider the situation and find a solution', but the fact was that the EU 'wants to reach an agreement with all Mercosur members ... The objective, our main goal is an association agreement between the EU and Mercosur, and we are convinced that this would be the best option both for Mercosur countries and for the EU' (MercoPress 30/5/2015). In effect, this statement suggested that the decision to push on with the negotiations without Argentina had to come from Mercosur, for it seems that the EU did not want to be seen as responsible making this decision.

After the summit in Brussels, it seemed that the EU would now accept a two-speed agreement with both Mercosur and individual Mercosur member states, with the Vice-president of Uruguay stating that 'I think the most positive side of the meeting in Brussels was the fact that German Chancellor Angela Merkel insisted on the need to formalize as soon as possible an EU/ Mercosur agreement, and if necessary a "two-speed" approach was acceptable' (MercoPress 18/6/2015).

\section{EU engagement with Mercosur}

In order to assess the level of ambition shown at the different stages of the negotiation process, it is necessary to contrast the presence of: (1) offers of negotiation mandates or agreements; (2) EU official policy pronouncements; (3) EU promises to Mercosur; and (4) plans for a potential relationship (see Figure 7.1). Furthermore, the negotiations discussed above demonstrate a high level of ambition due to the presence of the following:

- EU official policy pronouncements

- Promises to Mercosur

- Plans for a potential relationship.

In addition to ambition, these negotiations also demonstrate a high level of commitment based on the following factors (Figure 7.2):

- Substantial content of agreements and of offers (including clear tariff arrangements) during the negotiations 


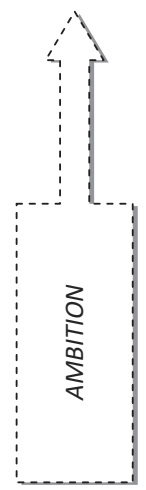

EU official policy pronouncements

Scenario 2: High

Promises to Mercosur

Plans for a potential relationship

Figure 7.1 Level of ambition: fourth stage

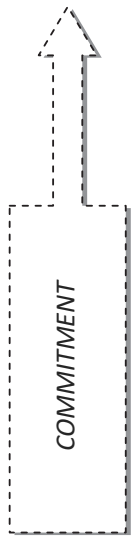

Substantial content of agreements and of offers during the negotiations

Scenario 2: High

Meetings either official or unofficial at any level: civil servant level, ministerial level, and/or head of states level

Figure 7.2 Level of commitment: fourth stage

- Aid, funding or technical help provided by the EU

- Meetings, either official or unofficial, at any level: civil servant level, ministerial level, and/or heads of state level.

Engagement is thus measured as high (Table 7.3). In light of the evidence presented above, the final section here will consider the six different arguments that were laid out in Chapter 2 (Table 7.4).

\section{Counterbalancing the US}

The argument that the EU was trying to counterbalance the influence of the US does not appear to be applicable during this period, particularly when we consider the fact that the EU and US were also negotiating the Transatlantic Trade and Investment Partnership (TTIP) agreement. 
Table 7.3 Measurement of the dependent variable, engagement: fourth stage

\begin{tabular}{|c|c|c|c|c|c|c|}
\hline \multicolumn{7}{|c|}{ Ambition } \\
\hline \multirow{6}{*}{ 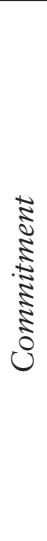 } & & Top & High & Medium & Low & None \\
\hline & Top & & & & & \\
\hline & High & & $\begin{array}{l}\text { Third and } \\
\text { fourth } \\
\text { stage: } \\
\text { high/high }\end{array}$ & $\begin{array}{l}\text { Second } \\
\text { stage: } \\
\text { med/high }\end{array}$ & & \\
\hline & Medium & & & & & \\
\hline & Low & & & & $\begin{array}{l}\text { First stage: } \\
\text { low/low }\end{array}$ & \\
\hline & None & & & & & \\
\hline
\end{tabular}

\section{Global aspirations}

The global aspirations argument suggests that an increase in the EU's involvement in Latin America would be an important part of the EU's attempt to secure a more influential role in the international arena. The fact that Mercosur has played a leading role in initiating negotiations during this period challenges this argument. At this particular moment, both Europe and the EU project were preoccupied by the economic crisis in the 'eurozone' which diverted their attention away from pursuing broader global aspirations.

\section{External federator}

In regard to promoting regional trade agreements, the EU continued to provide both funding and technical expertise. This is a role that the EU has played from the very outset. The EU continued to play this role by providing funding for the regional integration project in South America. However, the EU's strategic partnership with Brazil in 2007 and the cooperation agreement with Uruguay in 2015, alongside the fact that the EU also seemed to accept bilateral negotiations with Mercosur countries, challenges the 'external federator' argument.

\section{Long-standing political, economic and cultural ties}

The suggestion that the EU's involvement in Latin America would increase as a result of the historical ties and shared values between the two regions 
Table 7.4 Competing arguments and the independent variables: fourth stage

\begin{tabular}{|c|c|c|c|c|}
\hline Independent variable & Expectation & $\begin{array}{l}\text { Independent } \\
\text { variable value }\end{array}$ & $\begin{array}{l}\text { Expectation } \\
\text { value }\end{array}$ & Met/confronted \\
\hline Counterbalancing the US & $\begin{array}{l}\text { If the US increases its involvement in LA, the EU } \\
\text { should increase its involvement. } \\
\uparrow U S=\uparrow E U \text { in LA }\end{array}$ & Low & Low & No \\
\hline Global aspirations & $\begin{array}{l}\text { If the EU increases its presence in international } \\
\text { affairs, the EU's involvement in LA should also } \\
\text { increase. } \\
\uparrow E U \text { in the world = } \uparrow E U \text { in LA }\end{array}$ & Top & Top & No \\
\hline External federator & $\begin{array}{l}\text { If LA becomes more integrated, the EU will increase } \\
\text { its relations with LA. } \\
\uparrow \mathrm{LA} \text { integration }=\uparrow E U \text { in LA }\end{array}$ & Top & Top & No \\
\hline Affinity & $\begin{array}{l}\text { An increase of shared values between the regions } \\
\text { should develop EU policy. } \\
\text { 个LA shared values = } \uparrow \text { EU in LA }\end{array}$ & Top & Top & No \\
\hline Interdependence & $\begin{array}{l}\text { If trade and investment between the EU and LA } \\
\text { increase, EU policy should also increase. } \\
\text { 个LA trade }=\uparrow E U \text { in LA }\end{array}$ & Low & Low & No \\
\hline Iberia & $\begin{array}{l}\text { If the influence of Spain and Portugal increase } \\
\text { within the EU, then the EU's involvement in LA } \\
\text { should increase. } \\
\uparrow S P+\text { PT influence = } \uparrow E U \text { in LA }\end{array}$ & Low & Low & No \\
\hline
\end{tabular}


does seem applicable to the third stage of EU-Mercosur relations. This is evidenced by the fact most EU member states showed a serious lack of interest in the region. Moreover, the fact that the EU was developing additional trade agreements with Asian and African countries - which could be seen as less similar to Europe - further counters this argument.

\section{Interdependence}

This argument suggests that an increase in the EU's involvement in Latin America will in response to increasing trade and FDI in Mercosur. The evidence presented above does not support this argument during this particular stage of the negotiations. The influence of business associations, such as the MEBF, played a more proactive role in Latin America than in the EU. Again, it is important to note that trade agreements with South America was not a key priority for all EU member states (see Tables 6.1 and 6.2).

\section{Spanish and Portuguese influence in the EU}

This argument suggests that the increase in the EU's interest in Latin America as a result of the influence of Iberian countries in the EU cannot be sustained. While the EU's Iberian member states created forums that would facilitate the negotiations, this momentum was primarily instigated by Mercosur countries. In other words, these negotiations could not be sustained by Iberian interest alone.

In summary, this section has assessed the dependent variable as well as linking it to the values of the independent variables at the third stage of policy negotiations. It has shown how, during this particular stage, none of the aforementioned arguments is sufficient terms of explaining how events unfolded. It has also shown that the degree of Europeanization declined. This supports the core argument this put forward here. The development of the EU policy towards Mercosur very much required the influence its Iberian members. However, this alone was not sufficient by itself. The realization of the EU's policy towards Mercosur was also dependent upon the proactive role played by Mercosur member states.

\section{Conclusion}

This chapter has examined the relaunching of the negotiations of an association agreement between the EU and Mercosur since 2010. It has explained how the different possible explanations for the first round of EU-Mercosur negotiations are not fully applicable to this second stage of agreement negotiations. This is due to the fact that these explanations have underestimated the importance of political 'momentum' when it comes to developing 
EU-Mercosur trade negotiations, especially the role of Mercosur. They have also underestimated the role played by Spain and Portugal inside the EU, both in relation to Latin America in general and Mercosur in particular.

This chapter has also described how the expansion of EU, which included the integration of twelve new member states who placed strong emphasis on the agricultural sphere of their national economies, also made negotiations more difficult. However, the fact that an agreement was not reached during the Doha Round appears to have helped the Mercosur and the EU to come closer together. We must also acknowledge that was that Mercosur had to improve its reputation as a regional group after variety of concerns expressed on this issue was also an important factor. More importantly, the interest shown by both Spain and Portugal, demonstrated through the Spanish presidency and the efforts of Barroso in his role as president of the European Commission, were also crucial to the relaunch of the negotiations.

Overall, this second round of negotiations encountered additional obstacles, primarily in response to the impact of the 2007 economic crisis, the reluctance shown by both existing and new EU member states towards develop a regional trade agreement with Mercosur and, in particular, Argentina. However, these two regional groups do not relaunch such negotiations if there is no realistic chance of achieving a successful agreement, as was the case with the CACM. 